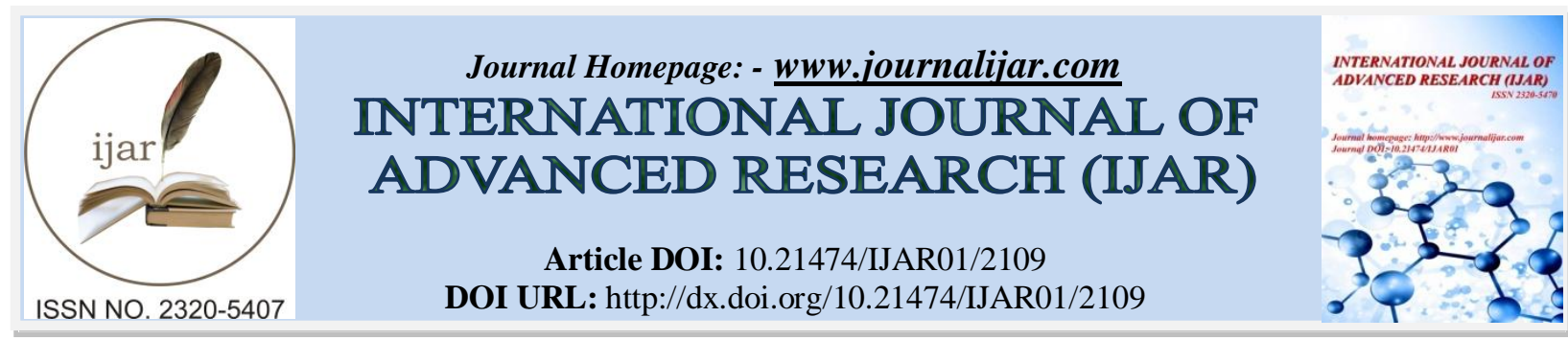

RESEARCH ARTICLE

\title{
SELECTION OF HIGH YIELDING SINGLE SPORE CULTURES OF VOLVARIELLA VOLVACEA (BULL.FRIES) SINGER.
}

*Mandeep Kaur and S.Dhanda, H.S. Sodhi.

Dpt. Of Microbiology, Punjab Agricultural University Ludhiana-141004.

\section{Manuscript Info}

Manuscript History

Received: 25 September 2016

Final Accepted: 27 October 2016

Published: November 2016

Key words:-

Volvariella volvacea, Mushrooms, enzyme, single spore isolates.

\begin{abstract}
Volvariella volvacea is a tropical mushroom with variable biological efficiency which can be stabilized through selection of single spore cultures. Nineteen single spore cultures, MV-1 to MV19 were isolated from three healthy fruit bodies of the parent, V. volvacea, VV-11 and analyzed for growth, enzyme production and yield potential. The growth rate was maximum in single spore culture MV-7 (30 mm/day). Maximum biomass production was recorded in MV-9 and MV-14 $(12.8 \mathrm{~g} / \mathrm{l}$ in both). The activity of endo-1, 4- $\beta$-glucanase (EC 3.2.1.4), exo-1, 4- $\beta$-glucanase (EC 3.2.1.91) was maximum in MV-7 (0.0481 and 0.0369 , respectively) while xylanase activity (EC 3.2.1.8) was maximum in MV-5(0.0404). The Laccase activity was maximum for MV-7 (1.61) followed by MV-3 (1.29) and MV-9 (1.16). On the basis of growth characteristics and enzyme activity six $V$. volvacea single spore isolates MV-6, MV-7, MV-9, MV-13, MV-14 and MV-18 were selected for yield trials on paddy straw. In comparison to yield of the parent $V$. volvacea, strain VV-11 $(13.28 \mathrm{Kg} / \mathrm{q}$ of dry straw, respectively), two single spore strains MV-7 and MV-14 had showed higher yield (15.32 and $16.13 \mathrm{Kg} / \mathrm{q}$ of dry straw, respectively) whereas number of fruit bodies was higher for the single spore culture MV-14 (2375 no./q of dry straw). The average weight of fruit body ranged between 5.8-8.3g. During the present study, two $V$. volvacea single spore cultures MV-7 and MV-14 have been selected as high yielding strains.
\end{abstract}

Copy Right, IJAR, 2016,. All rights reserved.

\section{Introduction:-}

Volvariella volvacea, an edible mushroom of the tropical regions belonging to the family Plutaceae of order Agaricales, ranks sixth among cultivated mushrooms in terms of annual world-wide production. It was first cultivated in China in 1822 (Chang 1969). It can be cultivated in the temperature range of $28^{\circ}$ to $32^{\circ} \mathrm{C}$ and relative humidity of $65-68 \%$. It is a fast growing mushroom to utilize cellulosic materials more effectively than any other cultivated mushroom. Paddy straw is the most common substrate for this mushroom. However this mushroom can also be cultivated on several crop residues like cotton waste, wheat straw and sugarcane industrial waste (Khan et al 1982).

Mushrooms are rich source of protein, vitamins, fats, carbohydrates, amino acids and minerals (Jiskani 2001). In mushroom fruiting bodies all essential amino acids, water soluble vitamins and all the essential minerals are present (Buigut 2002). The biological efficiency of a mushroom species is mainly attributed to its hydrolytic enzymes 
system (Chen et al 2003) and the biological efficiency is very low in paddy straw mushroom (about $10 \%$ to $15 \%$ on rice straw) in comparison to other popularly cultivated mushrooms (Chang 1974). This mushroom can produce an array of lignocellulolytic enzymes such as endo-1, 4- $\beta$-glucanase (EC 3.2.1.4), exo-1, 4- $\beta$-glucanase (EC 3.2.1.91), xylanase (EC 3.2.1.8) and laccase (EC 1.10.3.2). The activities of hydrolytic enzymes responsible for mycelial colonization (cellulases) and sporophore formation (laccase) have been found to vary in different strains of $V$. volvacea (Ahlawat et al 2005, 2008, Chen et al 2003).

Cultivation of Volvariella volvacea in Punjab has been successfully practised but face a lot of variation in its biological efficiency which could be stabilized through selection of stable single spore cultures. Present study was aimed at evaluation of pre-screened parent strains and single spore cultures for their variation and selection in growth rate, enzyme producing capability and yield potential.

\section{Methodology:-}

The cultures and their maintenance:-

The pure culture of Volvariella volvacea, strain VV-11 used in the present investigation was procured from Culture Collection Bank, Mushroom Research Complex, Punjab Agricultural University, Ludhiana. Throughout the study the culture was maintained on Potato Dextrose agar (PDA) medium at $30 \pm 2^{\circ} \mathrm{C}$ and was sub-cultured at the regular interval of three weeks.

\section{Cultivation of $V$. volvacea, VV-11:-}

Cultivation of $V$. volvacea, VV-11 was carried out using paddy straw (Khanna and Kapoor 2007). The spawn of Volvariella volvacea, VV-11 was prepared on wheat grains. Paddy straw bundles (each weighing 500g) were soaked in $1.5 \% \mathrm{CaCO}_{3}$ mixed with water for $16 \mathrm{~h}$ to attain a moisture level of 65-68\%. Paddy straw bundles were arranged as bed each comprising 22 bundles $(5 \times 4+2)$. Observations on spawn run, first harvest, mushroom yield for 3 weeks and average weight of fruit body and incidence of disease were recorded.

\section{Spore print and Single spore cultures:-}

Three healthy mushroom fruit bodies were fixed in pre sterilized spore collection assembly to shed their spores. These spores were collected on white filter paper as off-white coloured powder. Single spore cultures were isolated using serial dilution technique on Complete Yeast Extract (CYM) agar medium plates containing dextrose - 20.0 g; Peptone - $2.0 \mathrm{~g} ; \mathrm{MgSO}_{4}-0.5 \mathrm{~g} ; \mathrm{KH}_{2} \mathrm{PO}_{4}-0.46 \mathrm{~g} ; \mathrm{K}_{2} \mathrm{HPO}_{4}$ - $1.0 \mathrm{~g}$; Yeast extract - $2.0 \mathrm{~g}$; Agar - $20.0 \mathrm{~g}$; water - 1000 $\mathrm{ml}$ and $\mathrm{pH}-6.5$. Nineteen single germinating spores were marked and transferred to CYM agar slants.

\section{Characterization of Single spore cultures:- \\ Growth study:-}

Linear growth rate and biomass production of Single spore cultures along with parent culture VV-11 was estimated on CYM agar plates and broth respectively. To estimate the linear growth, bits of equal size (10 mm) were placed from master plates on to the CYM agar plates, incubated at $30 \pm 2^{\circ} \mathrm{C}$. Linear growth was measured as mm per day. To estimate the biomass production, bits of equal size $(10 \mathrm{~mm})$ were inoculated from master plates on to the CYM broth $\left(50 \mathrm{ml}\right.$ each flask), at $30 \pm 2^{\circ} \mathrm{C}$. Each flask was filtered after of 10 day of incubation onto preweighed Whatmann No. 1 filter paper. The mycelium was dried in an oven at $55^{\circ} \mathrm{C}$, till it attained constant weight. The weight of dry mycelium obtained was recorded, as the difference of the final and initial values.

\section{Extracellular enzyme activity:- \\ Preparation of Extract:-}

Nineteen single spore cultures screened for enzyme activity. Enzyme extract was prepared using mushroom minimal medium (MMM) broth containing L-Asparagine - $1.6 \mathrm{~g}$; Dextrose - $20.0 \mathrm{~g} ; \mathrm{MgSO}_{4} .7 \mathrm{H}_{2} \mathrm{O}-0.5 \mathrm{~g} ; \mathrm{KH}_{2} \mathrm{PO}_{4}-0.46 \mathrm{~g}$; $\mathrm{K}_{2} \mathrm{HPO}_{4}-1.0 \mathrm{~g}$; Thiamine Hydrochloride - $0.125 \mathrm{~g}$; Agar -20.0 g; water - $1000 \mathrm{ml}$ and pH- 6.5. Basal broth (30 mL) was supplemented with Cellulose (@ $0.5 \mathrm{~g} / \mathrm{flask}$ ) as inducer for extracellular enzyme production. These flasks were then incubated at $30 \pm 2^{\circ} \mathrm{C}$ for 10 days. Flasks were shaken daily up to 10 days. Each flask was filtered onto Whatmann No. 1 filter paper. The filtrate was collected in capped vials and stored at $-4^{\circ} \mathrm{C}$ to estimate the enzyme activity.

\section{Enzyme assays:-}

Cellulases and xylanase were assayed by the method of Sandhu and Kalra (1982). Enzyme extract (0.5ml) was mixed in $0.5 \mathrm{ml}$ of substrate. Substrates used for exoglucanase (FPase, EC 3.2.1.91), endoglucanase (CMCase, EC 
3.2.1.4) and xylanase (EC 3.2.1.8) were Whatmann No.1 filter paper, carboxymethyl cellulose (CMC) and xylan, respectively, prepared in $0.1 \mathrm{M}$ acetate buffer separately. For exo-1, 4- $\beta$-glucanase, 8 discs of $0.6 \mathrm{~cm}$ diameter Whatmann filter paper No.1 was used as substrate and $0.5 \mathrm{ml}$ of $0.1 \mathrm{M}$ acetate buffer was mixed. Solutions were kept in the waterbath at $45^{\circ} \mathrm{C}$ for $6 \mathrm{~h}$ and then $1 \mathrm{ml}$ of alkaline CuSO 4 was added in each test tube and again kept in boiling waterbath at $100^{\circ} \mathrm{C}$ for 20 minutes. Solutions were taken out of waterbath and $1 \mathrm{ml}$ of Arsenomolybdate solution was mixed in each test tube. Final volume was made up $(10 \mathrm{ml}$ of each test tube) with the help of distilled water. After cooling for 30 minutes at room temperature absorbance was read at $540 \mathrm{~nm}$, using UV- visible spectrophotometer (Elico SL-164). Laccase (EC 1.10.3.2) was assayed following by Dhaliwal et al (1992). using a reaction mixture consisting of $1 \mathrm{ml}$ of enzyme filtrate and $3 \mathrm{ml}$ of Guaicol substrate prepared in $0.1 \mathrm{M}$ sodium phosphate buffer $(\mathrm{pH}$ 6.0. Change in absorbance was observed at $495 \mathrm{~nm}$. The units used for cellulases and xylanase is $\mu$ mole glucose release $\mathrm{h}^{-1} \mathrm{ml}^{-1}$ and for laccase change in absorbance by $0.001 \mathrm{~min}^{-1} \mathrm{ml}^{-1}$.

\section{Protein estimation:-}

Mushroom extract for each single spore culture along with parent culture VV-11 was prepared using MMM media. To the $2 \mathrm{ml}$ of culture sample, $2 \mathrm{ml}$ chilled 20\% trichloro acetic acid (TCA) was added and mixed thoroughly. After aging for 1 hour at $4^{\circ} \mathrm{C}$, the contents were centrifuged (14000 rpm x g for 15minutes) and the precipitates were dissolved in $2 \mathrm{ml} 0.1 \mathrm{~N} \mathrm{NaOH}$. Protein was determined according to the method of Lowry et al (1951).

\section{Selection of single spore cultures for yield evaluation:-}

On the basis of growth characteristics and enzyme activity of single spore cultures, out of 19 single spore cultures six strains MV-6, MV-7, MV-9, MV-13, MV-14 and MV-18 along with parent culture VV-11 were selected for the yield evaluation trials on paddy straw beds under natural climatic conditions. The spawn of each single spore culture was prepared on wheat grains. Paddy straw bundles were wetted to a moisture content of $66-71 \%$. The beds were laid in growing rooms. The temperature and relative humidity during the crop period was recorded. The observations were made on spawn run period, pin head appearance, number of fruit bodies and weight of fruit bodies.

\section{Results and discussion:-}

Volvariella volvacea strain VV-11 was the high yielding strain evaluated during All India Coordinated Research Project trials (Annual Report 2012-13). The spawn of Volvariella volvacea, VV-11 was prepared on wheat grains. Paddy straw bundles (each weighing $500 \mathrm{~g}$ ) were soaked in $1.5 \% \mathrm{CaCO}_{3}$ mixed with water for $16 \mathrm{~h}$ to attain a moisture level of $65-68 \%$. Paddy straw bundles were arranged as bed each comprising 22 bundles $(5 \times 4+2)$. Observations on spawn run, first harvest, mushroom yield for 3 weeks, average weight of fruit body and incidence of disease were recorded.

Table 1:- Cultivation of Volvariella volvacea, VV-11

\begin{tabular}{|l|l|l|l|l|l|}
\hline Replicate & $\begin{array}{l}\text { Spawn run } \\
\text { (Days) }\end{array}$ & $\begin{array}{l}\text { First harvest } \\
\text { (Days) }\end{array}$ & $\begin{array}{l}\text { Yield } \\
\text { (Kg/q of dry } \\
\text { straw) }\end{array}$ & $\begin{array}{l}\text { NFB } \\
\text { (no./q of dry } \\
\text { straw) }\end{array}$ & $\begin{array}{l}\text { Average wt. of } \\
\text { fruit body } \\
\text { (g) }\end{array}$ \\
\hline 1 & 5 & 8 & 14.83 & 2213 & 6.7 \\
\hline 2 & 7 & 13.79 & 1723 & 8.0 \\
\hline 3 & 6 & 15.80 & 2135 & 7.4 \\
\hline 4 & 5 & 7 & 11.85 & 1669 & 7.1 \\
\hline 5 & 5 & 7 & 12.84 & 1860 & 6.9 \\
\hline Mean & $\mathbf{5 - 7}$ & $\mathbf{7 - 9}$ & $\mathbf{1 3 . 8 2}$ & $\mathbf{1 9 2 0}$ & $\mathbf{7 . 2}$ \\
\hline CD at 5\% & - & - & $\mathbf{1 . 1 6 4}$ & $\mathbf{1 9 9 . 7 2}$ & - \\
\hline
\end{tabular}

\section{No of replicates: 5}

Date of sowing: 18.05.2013

Date of Fragmentation: 25.05.2013

Spawn run was complete in 5-7 days of spawning and first harvest was made between 7-9 days. Mushrooms were first harvested on $8^{\text {th }}$ day of spawning to give $13.82 \mathrm{Kg} / \mathrm{q}$ paddy straw, yield and giving 1920 number of fruit bodies in 3 week harvest (Table 1).The average weight of fruit body was 7.2gms. Biological efficiency was $13.82 \%$. Tripathy et al (2011) recorded that biological efficiency was affected by substrate. Wheat and rice bran spawn resulted with the highest biological efficiency in $V$. volvacea (13.6\%), V. diplasia (12.4\%) and the largest number of mushroom production. Wheat and banana leaf spawn yielded the lowest with the B.E. (8\%) in V. volvacea and 
wheat and sugarcane baggase (7.6\%) in V.diplasia. A significantly higher yield $\left(5.38 \mathrm{~kg} / \mathrm{m}^{2}\right)$ was observed in cotton waste medium in indoor method while the lowest value $\left(1.73 \mathrm{~kg} / \mathrm{m}^{2}\right)$ was observed from paddy straw in outdoor method. The highest number of fruits $\left(49.7 \mathrm{~kg} / \mathrm{m}^{2}\right)$ was recorded in cotton waste medium in indoor method while the lowest $\left(17 \mathrm{~kg} / \mathrm{m}^{2}\right)$ was given by the paddy straw compost in outdoor method (Rajapakse 2011).

Table 2: Growth Characterstics of Volvariella volvacea Single spore cultures

\begin{tabular}{|c|c|c|c|c|c|c|c|}
\hline \multirow[t]{2}{*}{$\begin{array}{l}\text { Single } \\
\text { sporeCultures }\end{array}$} & \multicolumn{4}{|c|}{$\begin{array}{l}\text { Growth in mm diameter } \\
\text { (mm per day) }\end{array}$} & \multirow{2}{*}{$\begin{array}{l}\text { Biomass } \\
\text { production } \\
(\mathrm{g} / \mathrm{L})\end{array}$} & \multicolumn{2}{|c|}{$\begin{array}{l}\text { Morphological Characteristics } \\
\text { On CYM agar medium }\end{array}$} \\
\hline & Day1 & Day2 & Day3 & Day4 & & Colour & Morphology \\
\hline MV 1 & 10.6 & 40.0 & 66.0 & 80.6 & 6.5 & Off-white & Sparse \\
\hline MV 2 & 22.0 & 49.2 & 78.0 & 90.0 & 5.3 & Off-white & Aerial \\
\hline MV 3 & 20.0 & 52.6 & 80.0 & 90.0 & 9.3 & Greyish & Mat type \\
\hline MV 4 & 13.2 & 42.0 & 74.0 & 90.0 & 6.6 & Brownish & Fluffy \\
\hline MV 5 & 20.0 & 46.0 & 66.0 & 90.0 & 8.0 & Off-white & Dense \\
\hline MV 6 & 17.2 & 58.0 & 90.0 & 90.0 & 4.6 & White & Sparse \\
\hline MV 7 & 10.6 & 42.6 & 74.0 & 90.0 & 9.3 & Off-white & Strandy \\
\hline MV 8 & 13.2 & 36.6 & 56.0 & 72.6 & 6.0 & Greyish & Aerial \\
\hline MV 9 & 17.2 & 46.0 & 74.0 & 90.0 & 12.8 & Off-white & Dense \\
\hline MV 10 & 20.0 & 43.2 & 66.0 & 83.2 & 8.6 & White & Mat type \\
\hline MV 11 & 22.0 & 44.0 & 66.0 & 82.0 & 7.3 & Off-white & Sparse \\
\hline MV 12 & 20.6 & 52.0 & 76.0 & 90.0 & 9.3 & Off-white & Mat type \\
\hline MV 13 & 25.2 & 56.0 & 77.2 & 90.0 & 11.8 & Brownish & Mat type \\
\hline MV 14 & 23.2 & 64.6 & 82.0 & 90.0 & 12.8 & Off-white & Dense \\
\hline MV 15 & 12.6 & 42.0 & 72.0 & 90.0 & 11.3 & Off-white & Dense \\
\hline MV 16 & 16.0 & 36.0 & 73.2 & 82.6 & 8.6 & Greyish & Fluffy \\
\hline MV 17 & 12.0 & 29.2 & 47.2 & 67.2 & 11.2 & Off-white & Fluffy \\
\hline MV 18 & 10.6 & 26.0 & 42.0 & 58.6 & 12.1 & Off-white & Sparse \\
\hline MV 19 & 10.0 & 32.6 & 50.6 & 72.6 & 8.0 & Off-white & Aerial \\
\hline Parent VV-11 & 13.5 & 38.7 & 61.6 & 83.7 & 7.6 & Off-white & Dense \\
\hline CD (5\%) & 3.88 & 6.28 & 5.73 & 3.32 & 2.53 & - & - \\
\hline
\end{tabular}

Media used: CYM agar for linear growth and CYM broth for biomass

Temperature for incubation: $32^{\circ} \mathrm{C}$

Incubation Period: 3-4 days for linear growth and 9-10 days for biomass production

Nineteen single spore cultures MV-1 to MV-19 along with the parent culture VV-11 were subjected to growth on CYM media (both agar and broth). On CYM agar the growth rate was maximum for MV-2, MV-13 and MV-14 on day 1, while it was maximum for MV-3, MV-6, MV-12 and MV-14 on day 2. On the 3rd day the growth (mm/day) was maximum for MV-2, MV-6, MV-7,MV-9, MV-12, MV-13, MV-14 and MV-16. On day 4 the growth rate was minimum for MV-8, MV-17, MV-18 and MV-19 (Table 3). In broth culture the biomass harvested was between 5.3 to $12.8 \mathrm{~g} / \mathrm{l}$ with maximum for MV-9, MV-3, MV-14, MV-15, MV-17 and MV-18 (Table 3).

26 strains of $V$. volvacea were grown on malt extract agar medium. The strains were characterized based upon the mycelial growth rate, aerial hyphae, type of growth and intensity of chlamydospores formed. Fourteen strains showed radial growth of 90 to $100 \mathrm{~mm}$ in 8 days, while 8 strains grew up to $60-70 \mathrm{~mm}$. Rest of the 4 strains grew very slowly and showed growth of 11 to $35 \mathrm{~mm}$. Most of the fast growing strains formed thin or thick fluffy growth with sufficient aerial hyphae and no chlamydospores on 8th day of growth. However, some exceptions were also noticed where in the fast growing strains, OE-272 and OE-274 with radial growth of $90 \mathrm{~mm}$ formed quite low level of aerial hyphae (Ahlawat 2011).

The enzyme assay of single sporecultures indicated maximum enzyme activity of endoglucanase (EC 3.2.1.4), exoglucanase (EC 3.2.1.91) and xylanase (EC 3.2.1.8) for the culture MV-7. The endoglucanase activity for MV-1, MV-2, MV-3 and MV-9 was in between 0.0312 to 0.0378 . While the endoglucanase activity was lower for culture 
MV-5 (0.0104). The exoglucanase activity for culture MV-4 (0.0120) was the lowest. Maximum xylanase activity was found in MV-5(0.0404) (Table4, Fig 4.4). The Laccase activity was maximum for MV-7 (1.61) followed by MV-3 (1.29) and MV-9 (1.16) with the lowest in MV-11 (0.23) (as shown in Table 3).

Enzyme activity was recorded in strain, OE-143, followed by OE-214, OE-139 and OE-215. Highest endoglucanase activity was recorded in the strain, OE-143, followed by $1.49 \mathrm{U}$ in OE-145 and $1.24 \mathrm{U}$ in OE-210. Highest $\beta$ glucosidase activity was recorded in the strain, OE-145, followed by $2.55 \mathrm{U}$ in $\mathrm{OE}-117$ and $2.50 \mathrm{U}$ in $\mathrm{OE}-210$. Xylanase activity was highest in strain, OE-215, followed by strains, OE-272, OE-213, OE-209, OE-117 and OE214. Highest activity of laccase was recorded in strain OE-143, followed by strains, OE-29, OE-145, OE-210 and OE-272. Variations in activities of extracellular enzymes in V. volvacea strains along with role of cellulases in mycelial colonization and laccase in sporophore formation have also been reported (Ahlawat et al 2008).

Table 3:- Enzyme Assay In Single spore Cultures of Volvariella volvacea.

\begin{tabular}{|c|c|c|c|c|c|}
\hline \multirow{2}{*}{$\begin{array}{l}\text { Volvariella } \\
\text { volvacea } \\
\text { single } \\
\text { sporecultures }\end{array}$} & \multirow{2}{*}{$\begin{array}{l}\text { Protein } \\
\text { Content } \\
(\mathrm{Mg} / \mathrm{L})\end{array}$} & \multicolumn{3}{|l|}{$\begin{array}{l}\text { Enzyme Activity } \\
\left(\mathrm{U} \mathrm{h}^{-1} \mathrm{ml}^{-1}\right)\end{array}$} & \multirow{2}{*}{$\begin{array}{l}\text { Laccases } \\
\left(\mathrm{U} \mathrm{min}^{-1} \mathrm{~mol}^{-1}\right)\end{array}$} \\
\hline & & Endoglucanase & Exoglucanase & Xylanase & \\
\hline MV 1 & 2.1 & 0.0315 & 0.0176 & 0.0187 & 0.94 \\
\hline MV 2 & 2.3 & 0.0326 & 0.0274 & 0.0249 & 1.03 \\
\hline MV 3 & 1.9 & 0.0312 & 0.0214 & 0.0186 & 1.29 \\
\hline MV 4 & 2.1 & 0.0118 & 0.0120 & 0.0179 & 0.63 \\
\hline MV 5 & 2.2 & 0.0104 & 0.0267 & 0.0404 & 0.43 \\
\hline MV 6 & 2.4 & 0.0179 & 0.0214 & 0.0190 & 0.39 \\
\hline MV 7 & 2.1 & 0.0481 & 0.0369 & 0.0356 & 1.61 \\
\hline MV 8 & 2.0 & 0.0119 & 0.0181 & 0.0171 & 0.97 \\
\hline MV 9 & 2.4 & 0.0378 & 0.0271 & 0.0336 & 1.16 \\
\hline MV 10 & 2.3 & 0.0219 & 0.0173 & 0.0191 & 0.62 \\
\hline MV 11 & 2.2 & 0.0245 & 0.0174 & 0.0225 & 0.23 \\
\hline MV 12 & 1.8 & 0.0238 & 0.0198 & 0.0215 & 0.66 \\
\hline MV 13 & 2.3 & 0.0333 & 0.0294 & 0.0264 & 1.05 \\
\hline MV 14 & 2.2 & 0.0199 & 0.0095 & 00174 & 0.54 \\
\hline MV 15 & 1.9 & 0.0213 & 0.0216 & 0.0194 & 0.80 \\
\hline MV 16 & 1.6 & 0.0264 & 0.0312 & 0.0205 & 0.79 \\
\hline MV 17 & 2.1 & 0.0209 & 0.0182 & 0.0174 & 0.45 \\
\hline MV 18 & 2.3 & 0.0188 & 0.0190 & 0.0159 & 0.77 \\
\hline MV 19 & 2.4 & 0.0229 & 0.0213 & 0.0183 & 0.76 \\
\hline Parent VV-11 & 2.4 & 0.0194 & 0.0166 & 0.0143 & 0.86 \\
\hline CD 5\% & - & 0.0032 & 0.0019 & NS & 0.35 \\
\hline
\end{tabular}

Exoglucanase, Endoglucanase and Xylanase activity- $\mu \mathrm{mol}$ glucose released $\mathrm{h}^{-1} \mathrm{~mol}^{-1}$

Laccase- Change in absorbance by $0.001 \mathrm{~min}^{-1} \mathrm{~mL}^{-1}$.

Data is mean of three replicates

Incubation temperature: $30 \pm 2^{0} \mathrm{C}$

$\mathrm{CD}$ at $5 \%$ level

Days of incubation- 12

Inducer: Cellulose $0.5 \mathrm{~g}$ each flask

Medium: Mushroom Minimal Media

On the basis of growth characteristics and enzyme activity six single spore cultures MV-6, MV-7, MV-9, MV-13, MV-14 and MV-18 were selected for yield trials. Six single spore cultures of Volvariella volvacea were grown on paddy straw under natural climatic conditions. . In comparison to the parent strain Volvariella volvacea, strain VV11, two single spore strains MV-7 and MV-14 had shown higher yield whereas number of fruit bodies was higher for the single spore culture MV-14. The yield potential for two single spore strains MV-6 and MV-18 was minimum. The average weight of fruit bodies ranged between $5.8-8.3 \mathrm{~g}$. 
Table 4:- Cultivation of Volvariella volvacea, single spore cultures

\begin{tabular}{|l|l|l|l|l|l|}
\hline Strain number & $\begin{array}{l}\text { Spawn run } \\
\text { (Days) }\end{array}$ & $\begin{array}{l}\text { First harvest } \\
\text { (Days) }\end{array}$ & $\begin{array}{l}\text { Yield } \\
\text { (Kg/q of dry } \\
\text { straw) }\end{array}$ & $\begin{array}{l}\text { NFB } \\
\text { (no./q } \\
\text { straw) }\end{array}$ & $\begin{array}{l}\text { Average wt. of } \\
\text { fruit body } \\
\text { (g) }\end{array}$ \\
\hline MV-6 & $8-11$ & $10-12$ & 3.18 & 475 & 6.7 \\
\hline MV-7 & $6-8$ & $10-12$ & 15.32 & 1845 & 8.3 \\
\hline MV-9 & $7-9$ & $10-12$ & 13.05 & 1717 & 7.6 \\
\hline MV-13 & $9-11$ & $13-15$ & 12.23 & 1675 & 7.3 \\
\hline MV-14 & $5-7$ & $8-10$ & 16.13 & 2375 & 6.8 \\
\hline MV-18 & $8-10$ & $12-13$ & 5.96 & 1027 & 5.8 \\
\hline Parent VV-11 & $6-8$ & $7-9$ & 13.28 & 1870 & 7.1 \\
\hline CD at 5\% & - & - & & - \\
\hline
\end{tabular}

No of single spore cultures: 6

Date of sowing: 14.08.2013

NFB: Number of fruit bodies
Crop Period: 20 days

Rate of spawn: 300g/bed

Out of 20 strains of screened for enzyme assays, 12 strains with varied enzyme activities were used for the yield evaluation trials on pasteurized paddy straw bundles. On pasteurized paddy straw bundles, strains, OE-274, OE-215, OE-272 and OE-55 showed very thick and fluffy growth, while strains, OE-210, OE-213 and OE-139 completely colonized the substrate but with very light (thin) mycelial growth. Mushrooms were harvested earliest in the strain, OE-274 after $20 \mathrm{~d}$ of spawning, followed by strains, OE-272, OE-139and OE-140. Highest mushroom yield of 12.36 $\mathrm{kg} \mathrm{q}-1$ dry substrate was recorded in the strain, OE-274, followed by $10.49 \mathrm{~kg}$ in OE-272 and $10.45 \mathrm{~kg}$ in OE-210 (Ahlawat et al 2008).

\section{Conclusion:-}

Nineteen single spore cultures of Volvariella volvacea strain VV-11 were isolated from three different fruit bodies. On the basis of linear growth, biomass production, and enzyme activity six of the nineteen single spore cultures were selected for cultivation. In comparison to the parent strain Volvariella volvacea, strain VV-11, two single spore strains MV-7 and MV-14 had shown higher yield whereas number of fruit bodies was higher for the single spore culture MV-14.

\section{References:-}

1. Ahlawat O P, Ahlawat K and Dhar B L (2005) Influence of lignocellulolytic enzymes on substrate colonization and yield in monosporous isolates and parent strains of Volvariella volovacea. Ind. J. of Microbiol. 45(3): 20510.

2. Ahlawat O P, Gupta P, Kamal S and Dhar B L (2005) High yielding strains of paddy straw mushroom,Volvariella volvacea. Mush. Research letters. 11(1):2.

3. Ahlawat O P, Gupta P, Kamal S and Dhar B L (2008) The development of molecular and biochemical markers for selecting a potential high yielding strain of paddy straw mushroom, Volvariella volvacea. $\mathrm{J}$ of Plant Biochem and Biotech (1): 57-63.

4. Ahlawat O P, Gupta P, Dhar B L, Sagar T G, Rajendranath R, Rathnam K (2008) Profile of the extracellular lignocellulolytic enzymes activities as a tool to select the promising strains of Volvariella volvacea. Indian $\mathrm{J}$ Microbiol 48(3):389-96.

5. Ahlawat O P, Singh R and Kumar S (2011) Evaluation of Volvariella volvacea Strains for Yield and Diseases/Insect-Pests Resistance Using Composted Substrate of Paddy Straw and Cotton Mill Wastes. Indian J Microbiol 51:200-05.

6. Buigut S.K. (2002) Mushroom production in sustainable small-scale farming system-opportunities and constraints: a survey of Uasin Gishu district. In: Proceedings of the Holticulture seminar on Sustainable Horticultural Production in the Tropics at Jomo Kenyatta, University of Agriculture \& Technology, Juja, Kenya, October 3-6, 2001, Kenya.

7. Chang S T (1969) A cytological study of spore germination of Volvariella volvacea. Bot Mag 82:102-09.

8. Chang ST (1974) Production of straw mushroom (Volvariella volvacea) from cotton wastes. Mush J 21: 348 54. 
9. Chen SC, Ma DB, Ge W and Buswell JA (2003) Induction of laccase activity in the edible straw mushroom, Volvariella volvacea. FEMS Microbiol Letters 218(1):143-48.

10. Dhaliwal R P S, Garcha H S and Khanna P K (1991) Regulation of lignocellulytic enzyme system in P. ostreatus Ind. J. of Microbiol.31: 181-84.

11. Jiskani M M (2001) Energy potential of mushrooms. The DAWN, Economic and Business Review (4):15-21.

12. Khan S M, Qadir A and Ramzan M (1982) Fungal mycelium as a source of protein for animal feed. Agric (Urdu) 21st National Sci Conf Sci Soci Pakistan (Abstr).

13. Khanna P K and Kapoor S (2007) Manual on Mushroom Production, Punjab Agricultural University, Ludhiana, Punjab, India.

14. Lowry O H, Rosenbrough N J, Farr A L and Randall R J (1951) Protein measurement with folin phenol reagent. J Boil Chem 193: 265-75.

15. Sandhu D K and Kalra M K (1982) production of Cellulases, Xylanases and Pectinases by Trich-oderma longibrachiatum on different substrates. Trans British mycol soc 79: 409-13.

16. Tripathi A, Patel A K, Sahoo T K (2011) Yield evaluation of paddy straw mushrooms various lignocellulosic wastes. Asian J Plant Sci 4:566-69. 